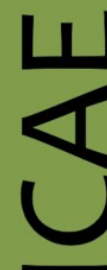

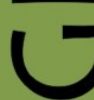

ex Instituto Archaeologico Universitatis de Rolando Eötvös nominatae

O

$\overrightarrow{0}$

山

$\leftarrow$

I

$\cup$

ه

$\leftarrow$

u

Ш

Z

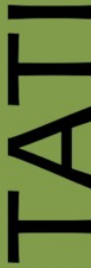

œ

ш

n

n

$\varnothing$
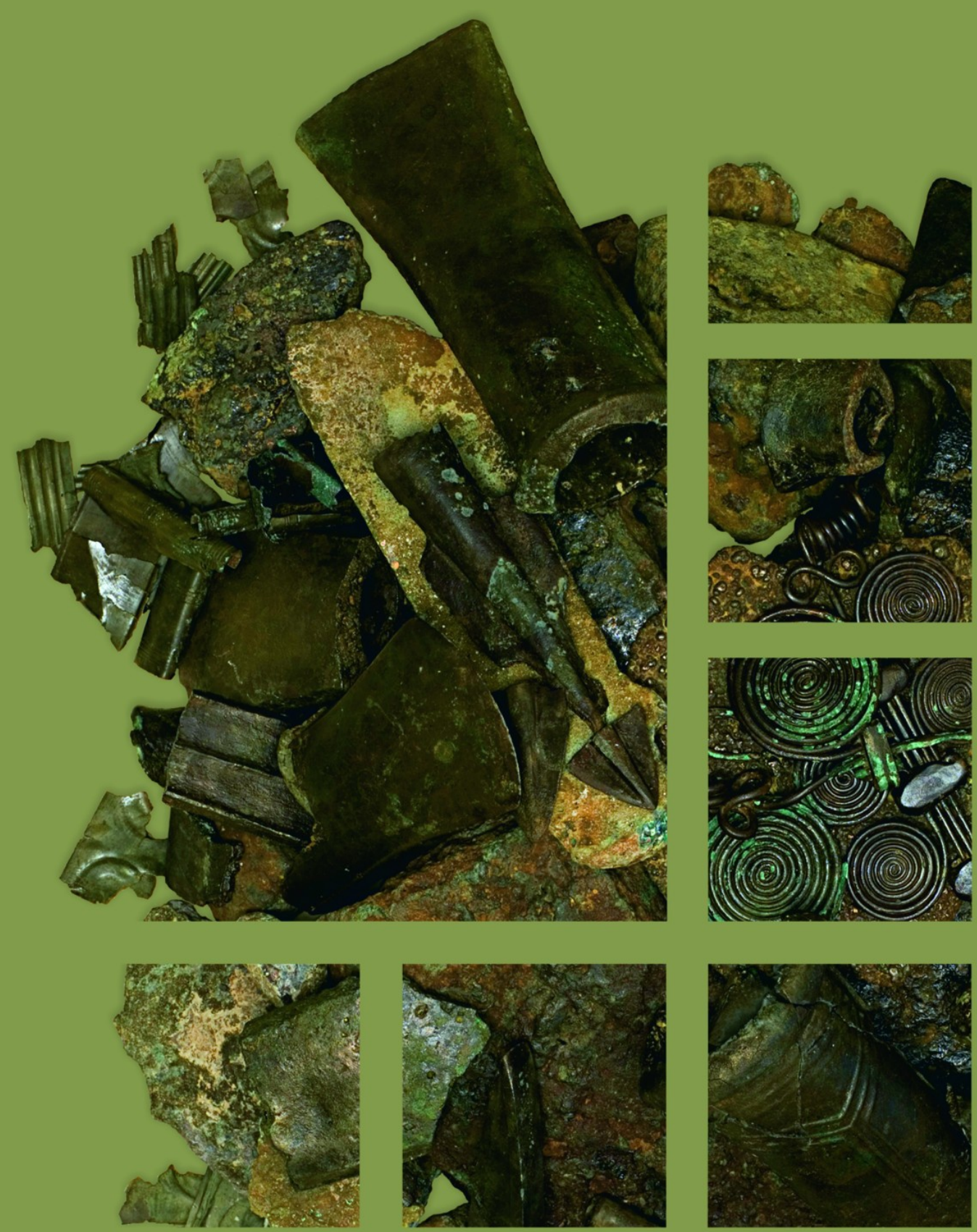


\section{Dissertationes Archaeologicae ex Instituto Archaeologico}

Universitatis de Rolando Eötvös nominatae Ser. 3. No. 2.

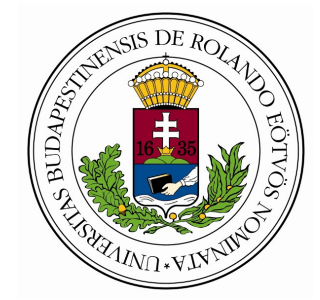

Budapest 2014 
Dissertationes Archaeologicae ex Instituto Archaeologico Universitatis de Rolando Eötvös nominatae

Ser. 3. No. 2.

Editor-in-chief:

DÁvid BARTus

Editorial board:

LÁsZló BARTOSIEWICZ

LÁSZLÓ BORHY

IsTVÁN FELD

GÁBOR KALLA

PÁL RACZKY

MiKLÓs SzABÓ

TIVADAR VIDA

Technical editors:

DÁvid BARTus

GÁBOR VÁCZI

ANDRÁs BÖDŐCS

DÁNIEL SZABÓ

Proofreading:

SZILVIA SzÖLLősI

Available online at http://dissarch.elte.hu Contact: dissarch@btk.elte.hu

$$
\begin{aligned}
& \text { PUBLIC } \\
& \text { KNOWLEDGE } \\
& \text { PROJECT }
\end{aligned}
$$

(c) Eötvös Loránd University, Institute of Archaeological Sciences

Budapest 2014 


\section{Contents}

\section{SElected PAPERS OF THE XI. Hungarian CONFERENCE on Classical Studies}

Ferenc BARNA

Venus mit Waffen. Die Darstellungen und die Rolle der Göttin in der Münzpropaganda

der Zeit der Soldatenkaiser (235-284 n. Chr.)

Dénes GABLER

A belsó vámok szerepe a rajnai és a dunai provinciák importált kerámiaspektrumában

Lajos MATHÉDESZ

Római bélyeges téglák a komáromi Duna Menti Múzeum gyújteményében

Katalin OtTOMÁNYI

Újabb római vicusok Aquincum territoriumán

Eszter SÜVEGH

Hellenistic grotesque terracotta figurines. Problems of iconographical interpretation

András SzABó

Some notes on the rings with sacred inscriptions from Pannonia

István VIDA

The coinage of Flavia Maxima Helena

\section{Articles}

Gábor TARBAY

Late Bronze Age depot from the foothills of the Pilis Mountains

Csilla SÁRó

Roman brooches from Paks-Gyapa - Rosti-puszta

András BöDőcs - Gábor KovÁcs - Krisztián ANDERKó

The impact of the roman agriculture on the territory of Savaria

Lajos JuHÁsz

Two new Roman bronzes with Suebian nodus from Brigetio

\section{FIELD REPORTS}

Zsolt MESTER - Norbert FARAGó - Attila KirÁLy

The first in situ Old Stone Age assemblage from the Rába Valley, Northwestern Hungary

Pál RACZky - Alexandra ANDERs - Norbert FARAgó - Gábor MÁRKus

Short report on the 2014 excavations at Polgár-Csőszhalom 
Preliminary Report on the first season of fieldwork in Berettyóúffalu-Szilhalom

Márton SzILÁgyi - András FüZESI - Attila VIRÁG - Mihály GASPARIK

A Palaeolithic mammoth bone deposit and a Late Copper Age Baden settlement and enclosure

Preliminary report on the rescue excavation at Szurdokpüspöki - Hosszú-dúlö II-III. (M21 site No. 6-7)

Kristóf FüLÖP - Gábor VÁcZI

Preliminary report on the excavation of a new Late Bronze Age cemetery

from fobbágyi (North Hungary)

Lőrinc TimÁr - Zoltán CzAJLik - András BöDőcs - Sándor PuszTA

Geophysical prospection on the Pâture du Couvent (Bibracte, France). The campaign of 2014

Dávid BARtus - László Borhy - Gabriella Delbó - Emese SzÁmadó

Short report on the excavations in the civil town of Brigetio (Szőny-Vásártér) in 2014

Dávid BARTus - László BorHy - Emese SzÁMADó

A new Roman bath in the canabae of Brigetio

Short report on the excavations at the site Szőny-Dunapart in 2014

Dávid BARTus - László Borhy - Zoltán CzAjlik - Balázs Holl -

Sándor PuszTA - László RuPNiK

Topographical research in the canabae of Brigetio in 2014

Zoltán CZAJLIK - Sándor BERECKI - László RUPNIK

Aerial Geoarchaeological Survey in the Valleys of the Mureș and Arieș Rivers (2009-2013)

Maxim MoRDovin

Short report on the excavations in 2014 of the Department of Hungarian Medieval

and Early Modern Archaeology (Eötvös Loránd University, Budapest)

Excavations at Castles Čabrad' and Drégely, and at the Pauline Friary at Sáska

\section{Thesis Abstracts}

Piroska Csengeri

Late groups of the Alföld Linear Pottery culture in north-eastern Hungary

New results of the research in Borsod-Abaúj-Zemplén County

Ádám Bíró

Weapons in the 10-11th century Carpathian Basin

Studies in weapon technology and methodology - rigid bow applications and southern import

swords in the archaeological material

Márta DARÓcZI-SzABó

Animal remains from the mid 12th-13th century (Árpád Period) village of Kána, Hungary

Károly BELÉNYESY

A 15th-16th century cannon foundry workshop in Buda

Craftsmen and technology of cannon moulding and the transformation of military technology

from the Renaissance to the Post Medieval Period 
István RINGER

Manorial and urban manufactories in the 17th century in Sárospatak

\section{BIBLIOGRAPHY}

László BORHY

565

Bibliography of the excavations in Brigetio (1992-2014) 


\title{
Manorial and urban manufactories in the 17th century in Sárospatak
}

ISTVÁN RINGER

Kazinczy Ferenc Museum

ringer.istvan@gmail.com

\begin{abstract}
PhD thesis submitted in 2014 to the Archaeology Doctoral Programme, Doctoral School of History, Eötvös Loránd University, Budapest under the supervision of István Feld.
\end{abstract}

\section{The objective of the dissertation}

The disseration is based on the evaluation of three workshops from the 17th century excavated at Sárospatak. These three are a cannon foundry workshop located at the outer castle of Sárospatak, the Haban craftsman yard which functioned at the Héce Quarter and a workshop producing footwear at the bastion in the northeastern corner, more specifically a group of finds connected to its activity.

Beside the information recorded during the discovery and comprehensive processing of the particularly rich find material revealed at these sites, we had the opportunity to evaluate them from the aspect of topography, economic and industrial history. Two of the revealed sites, the cannon founry and the Haban yard are connected through the Sárospatak castle as the center of the Hungarian Rákóczi-estates, as well as the treasury and the partial order party and biggest receiver of the material goods created by the crafts of the lordship. The cannon foundry may be considered as a kind of symbol for the economic performance of the Rákóczi-estate. Also, it could be valued as the most important part of a methodically created structure. The deliberate industrial politics and economic aspect of the lordship played an important role in the settling of the New-Christians in Sárospatak, who were considered to be outstanding master craftsmen of theire time. Finds related to the footwear producing workshop, discovered by lucky coincidence, demonstrate leather industry, a segment of the most important and most prestigious crafts in the 17th century country town of Sárospatak. It is very rare that opportunity arises to investigate such workshops with archeological methods.

The start of the Rákóczi - occupancy in 1616 was the beginning of a significant prosperity era in the history of the 17th century Sárospatak. The rule of I. György Rákóczi, who became the Price of Transylvania in 1630, and his wife Zsuzsana Lorántffy represents in almost every aspect the golden age for the castle until the death of the princess in 1660 . The chronology of the three archeological sites which are also the keystones of this paper - out of which the cannon foundry and the Haban yard are directly related to the prince, respectively the ruler couple - belong mostly also to this period. 


\section{Methods of processing}

Besides the summarizing of economic and industrial history-related sources, in my thesis I devoted time to the collection and evaluation of topographycal data in general and regarding the particular workshops. This work was promising not only due to the reconstruction of the topography of the 17th century town - in connetction with which I dealt with the to pographic characteristics created by the symbiosis of the castle and the town - but especially because of the results revealed in the cannon foundry. I attempted to reconstruct the 17th topography of the southern part of the outer castle, presenting those lordship buildings near to the cannon foundry which may be interrelated directly or indirectly with the discovered workshop and highlight the military function of the castle in a more nuanced way. The most crucial part of the thesis is however the introduction and evaluation of the archeological sources in connection with all three workshops. Observations during the fieldwork and the revealed finds gave the opportunity for the reconstruction of the production in all cases, even if to a different depth due to the different potentialss/conditions of the discoveries.

The significance of the cannon foundry and the Haban yard exploration goes not only beyond Sárospatak but also the borders of Hungary. In compliance with this I tried to summarize and use the international results of the research in both topics as deeply as possible.

\section{Archeological research of the cannon foundry at Sárospatak}

According to the evidence of the sources the workshop was created by the reconstruction of a former one which was continuously functioning, with shorter breaks from 1631 until 1648. The discovery of the cannon foundry at Sárospatak, one of the leading industrial workshops of the country at that time, gave us the opportunity to reconstruct all of the work phases of the technology for the casting of cannons. Stratigraphical and building historical observations of the archeological research fit well enough and in some cases complete the rich picture - known from source material related to Sárospatak. I attempted to reconstruct and describe the principles of operation of the flame furnace combined with brazier and melting space which is considered to be the most important part of the workshop. Besides the recent results of a furnace in Buda from the turn of the 15th and 16th centuries, which is regarded to be the only archeological parallel, I used primarily the written sources and illustrations related to Western-European cannonry tracts from the Early Modern Age.

I could reconstruct the revealed furnace in Sárospatak and most of its functional parts. During the archeological excavation the rebuilding and repairing of the furnace resulted in many substantive observations. The furnace may be classified into the type of the so-called flame furnaces, which spread in the European bronze foundries at the turn of the 15th and 16th centuries and became common by the 17th century. The flame furnace was a casting equipment which replaced the former pit furnace, working on higher capacity than the pit furnace and was recognized as the most important technological element of permanent casting houses.

During the discovery of the workshop, a rich assembly of finds wasrevealed, which could be connected to the production of 17th century bronze cannons work phases of which require special craft knowledge. Together with the defining of special findings occurring as workshop waste, I presented and evaluated the production of molds and the processes of metal 
melting and casting with the help of rich source groups related to the topic, mainly from the Early Modern and Modern Era, as well as with the results from natural scientific examinations performed on the findings. I also mentioned related sources from Sárospatak regarding certain work phases. I likewise dealt with technological stages (e.g. drilling cast iron pipes) whose archeological evidence has not been revealed so far, but we may count on their existence out of technological necessity.

\section{Archeological research of the Haban yard at Sárospatak}

The investigation of Habans settled in Sárospatak by I. György Rákóczi plays a significant role from cultural historical and industrial historical view. The Haban yard at Sárospatak is the only one within the borders of Hungary which could be examined well enough as its present territory is rarely built in. Excavations made on the site, which could be precisely located thanks to sources from historic records, revealed new results concerning Haban pottery methods and products. With the help of finds discovered during the archeological research and related to pottery technology, I presented the most important master-strokes. I also compared the observations with the results acquired so far in the topic. In relation with the genesis of Hungarian Haban pottery I reviewed in detail the results of Moravian examinations and evaluated the archeological findings partly in connection with these observations. Scraps revealed as waste from pottery made with the faience technique, which is closely interwined with Habans, proved that Haban potters dealt with the production of faience pottery with a white, blue, manganese violet and turquoise green base glaze. One of the artifacts represented in the highest number in the find assembly were the dishes - produced with lead-glazed technique - used in the households of the Habans. These forms and motifs were quite different from the known products of the early modern Hungarian pottery. When presenting the specific form groups of artifacts, I emphasized the formal characteristics which can possibly be evaluated as Haban specifics.

According to the pots occurring as semi-finished incineration waste, it is presumable, that the Habans of Sárospatak dealt with dish types (flattened globular jug, filter jug, jug with ears flange) unknown in the Moravian tradition, which can be associated with the production to the local market.

The excavated finds show that the Haban potters also made stove tiles. A high amount of stove tiles showing incineration waste were found on the site, which are known from several early modern sites of the region, and this can illuminate a new context for the research in the area of early modern stove tiles.

\section{Shoemaker workshop in Sárospatak in the 17th century}

One of the rarest artifacts of the archaeological excavations are organic materials, for example the remains of leather. The leather findings from the 17th century found on the basement level of a house in the foreground of the northeast corner bastion of the outer castle of Sárospatak are unique in the Hungarian archaeological material. Thanks to the lucky circumstances of the discovery as well as the quick and efficient restoration work, not just soles but uppers, shanks, linings were found. Also characteristics of contemporary western type footwear fragments have been found, which are unknown in Hungarian archaeological 
literature. During the processing, a number of small details and data could be recorded that showed substantive results from the point of view of production techniques.

In addition to the remains of footwear, unique leather-working tools were revealed as well, which, supplemented by the examination of the leather findings, bore some important lessons for the knacks of making footwear and the different types of footwear in the 17th century. According to the results of processing, the finds can certainly be connected to a workshop which dealt with the production of new footwear and the repairing of old ones. Finding raw material as well points to the production of new goods. This is proven by the existence of the typically curved forms - from cutting waste - and hairy leathers among the finds. However, the repairing activity is clearly tangible. The recycling of the wrecked footwear is confirmed by the narrow cut of seam edges and the occurring repair patches. It is also proven by the deformation and the wear on the soles. 